Tér és Társadalom 18. évf. 2004/1. 107-126. p.

\title{
KITEKINTÖ
}

\section{AZ OSZTRÁK TERÜLETI TERVEZÉS JOGI SZABÁLYOZÁSÁNAK VIZSGÁLATA}

\author{
(System of the Austrian Spatial Planning) \\ FINTA ISTVÁN
}

Kulcsszavak:

teriuleti tervezés terilletrendezés területi programozás regionális politika jogi szabályozás

A tanulmányban három olyan jogszabaly bemutatására kerill sor, amelyek kiválasztásánál szerepet játszott a terïleti tervezés jogi szabályozásának központi szerepe, illetöleg olyan terilleti rendszer kiala. kítása és szabályozása, amely közel áll a magyar területi beosztási rendszerhez. E három tartományi törvény a burgenlandi, illetve a voralbergi területi tervezésról szóló tartományi törvény, valamint a tiroli területrendezési törvény. A területrendezés olyan tág kategória Ausztriában, amelybe belefér a mi fogal. maink szerint értelmezett területfejlesztés-rendezés, területi tervezés, söt a regionalis politika is. Ugyanakkor a vizsgált jogszabályok alapján megállapitható, hogy az egyes tartományi törvények területi tervezésre vonatkozó részei elósegíthetik mind a hazai értelemben vett területfejlesztés, mind pedig a területrendezés - különösen az alapelvek, célok meghatározására vonatkozó-jogszabályi rendezését.

\section{Bevezetés}

A területi tervezésre vonatkozó osztrák jogi szabályozás bemutatása elött szükséges néhány olyan sajátosságra felhívni a figyelmet, melyek hiányában nehezen lenne értelmezhetö az ausztriai terủleti tervezés tartalma és eljárási rendszere.

Ausztria szövetségi állam, ezáltal a tartományok igen jelentős autonómiával, önálló szabályozási jogosítványokkal rendelkeznek. Ezt az önállóságot csak tovább erösíti az a tény, hogy - a szomszédos Svájccal vagy Németországgal ellentétben Ausztriának szövetségi szinten nincs területrendezési törvénye. A területrendezés jogi szabályozása és gyakorlati végrehajtása így a tartományok szintjén zajlik (1. táblázat). A tartományok mindegyike rendelkezik területrendezési, illetve területi tervezés címủ törvénnyel, szemben például Németországgal, ahol ezt a kifejezést kizárólag a szövetségi szint számára tartják fenn, alatta pedig tartományi, regionális tervezésről beszélnek. A területi tervezés Ausztriában csupán egy bizonyos része, részhalmaza a területrendezésnek. „A területrendezés a közjogi testületek köz- és magánjogi intézkedéseinek (aktusainak) összessége, melyek arra irányulnak, hogy a terület egésze meghatározott politikai célkitüzéseknek megfelelően alakuljon. Ez vonatkozik a gazdasági, szociális, kulturális viszonyokra egyaránt. A területrendezés ezentúl nemcsak előre tervezett földhasználatot jelent, hanem minden olyan, a térre vonatkozó, ill. hatást gyakorló intézkedést, amely az adott terület 
Finta István : Az osztrák területi tervezés jogi szabályozásának vizsgálata.

Tér és Társadalom 18. évf. 2004/1. 107-126. p.

alakulására valamilyen hatást fejt ki.” (Schindegger 1999, 32) „Összefoglalva megállapítható, hogy a területrendezés feladata egyrészt a társadalom és a gazdaság területi igényeinek, másrészt a meglévő területi potenciálok közötti kiegyenlítés megvalósítása." (Schindegger 1999, 34)

\section{TÁBLÁZAT \\ Az osztrák területi tervezés rendszere}

(Analyse of the Legal Regulation of the Austrian Spatial Planning)

\begin{tabular}{|c|c|c|c|c|}
\hline Államszerkezet & $\begin{array}{l}\text { Tervezési } \\
\text { szintek }\end{array}$ & $\begin{array}{c}\text { Jogi } \\
\text { szabályozás }\end{array}$ & $\begin{array}{l}\text { Tervezési } \\
\text { eszközök }\end{array}$ & $\begin{array}{c}\text { Tényleges } \\
\text { (materiális) } \\
\text { tartalom } \\
\end{array}$ \\
\hline \multirow{3}{*}{$\begin{array}{c}\text { Szövetségi } \\
\text { (nemzeti) szint }\end{array}$} & \multicolumn{2}{|c|}{\begin{tabular}{|c|} 
Osztrák terület- \\
rendezési \\
koncepció
\end{tabular}} & & \multirow{3}{*}{$\begin{array}{c}\text { Jogi irányelvek } \\
\text { Ajánlások }\end{array}$} \\
\hline & Ágazati tervek & $\begin{array}{c}\text { Szövetségi } \\
\text { kompetencia }\end{array}$ & & \\
\hline & \multicolumn{2}{|c|}{$\begin{array}{c}\text { Osztrák területrendezési } \\
\text { konferencia } \\
\text { ÖROK }\end{array}$} & & \\
\hline Tartományok & $\begin{array}{l}\text { Területrendezés } \\
\text { és tervezés, } \\
\text { regionális ter- } \\
\text { vezés }\end{array}$ & $\begin{array}{c}\text { Területrendezési } \\
\text { törvény } \\
\text { Területi terve- } \\
\text { zési törvény }\end{array}$ & \begin{tabular}{|c|} 
Területi szint \\
feletti terület- \\
rendezési \\
programok \\
Tartományi \\
területrendezési \\
programok \\
Regionális és \\
ágazati \\
programok
\end{tabular} & \begin{tabular}{|} 
Helyi szint \\
feletti \\
célkitúzések \\
Intézkedési \\
katalógus a \\
megvalósítás \\
érdekében
\end{tabular} \\
\hline \multirow{3}{*}{$\begin{array}{l}\text { Önkormány- } \\
\text { zatok }\end{array}$} & $\begin{array}{c}\text { Település- } \\
\text { fejlesztési terv }\end{array}$ & \begin{tabular}{|c|} 
Területrendezési \\
rendelet \\
Településfej- \\
lesztési rendelet
\end{tabular} & \begin{tabular}{|c|} 
Helyi fejlesztési \\
program \\
Helyi fejlesztési \\
koncepció
\end{tabular} & $\begin{array}{c}\text { Célkitüzés és } \\
\text { intézkedési } \\
\text { katalógus }\end{array}$ \\
\hline & & & $\begin{array}{c}\text { Terület felhasz- } \\
\text { nálási terv }\end{array}$ & \begin{tabular}{|c|} 
A területhasz- \\
nálat kimutatása \\
Osztályozási \\
katalógus \\
\end{tabular} \\
\hline & & & Beépítési terv & $\begin{array}{c}\text { Konstrukciós } \\
\text { feltételek meg- } \\
\text { állapítása } \\
\end{array}$ \\
\hline
\end{tabular}

Forrás: Zehetner 2001, 111. o. alapján. 
A területrendezés tehát olyan tág kategória Ausztriában, amelybe belefér a mi fogalmaink szerint értelmezett területfejlesztés-rendezés, területi tervezés, söt a regionális politika is.

Tartományi szinten kilenc területrendezési törvény megalkotására került sor az ötvenes, hatvanas években. (Tartalmilag azóta jelentösen megújultak, különösen a kilencvenes években az EU csatlakozás küszöbén.) A törvények középpontjában a helyi szint feletti tervezés eszközrendszere, illetve annak felépítése áll. Ezentúl - az egyik legrészletesebben szabályozott terület - az önkormányzatok helyi tervezésének megvalósítására vonatkozó kötelezettségeire vonatkozik.

Az alábbiakban három olyan jogszabály bemutatására kerül sor, amelyek kiválasztásánál szerepet játszott a területi tervezés jogi szabályozásának központi szerepe, illetőleg olyan területi rendszer kialakítása és szabályozása, amely közel áll a magyar területi beosztási rendszerhez. $\mathrm{E}$ három tartományi törvény a burgenlandi, illetve a voralbergi területi tervezésröl szóló tartományi törvény, valamint a tiroli területrendezési törvény.

A jogszabályok váza, felépítése jelentösen hasonlít egymáshoz, azonban tartalmi szempontból nem csekély eltérések fedezhetök fel az egyes tartományi törvények között. Az egyes jogszabályok tartalmi rendelkezéseinek bemutatását a burgenlandi területi tervezésröl szóló törvény elemzésével kezdjük.

\section{A burgenlandi területi tervezésröl szóló tartományi törvény}

A burgenlandi területi tervezés szabályozására 1969-ben született az elsỏ törvény, melyet azóta 13 ízben módosítottak (8 alkalommal 1990-2002 között).

A törvény három fejezetre tagozódik, az első fejezet foglakozik a területi tervezés szabályozásával, a második fejezet a helyi szintủ területi tervezés elemeit részletezi (a legnagyobb terjedelmü fejezet), végül a harmadik fejezet a hatályba léptető rendelkezések néhány paragrafusát tartalmazza.

\section{Alapelvek, célok}

Az első fejezet meghatározza a területi tervezés alapelveit és céljait. A burgenlandi szabályozás értelmében a területi tervezés (tartományi tervezés) a tartomány, illetve ezen belül egyes területekre vonatkozó olyan átfogó tevékenység, amely a természeti adottságok, a szociális és kulturális követelmények, a környezetvédelem és a közösségi jólét megfelelő rendszerének kialakítását célozza.

A területi tervezés céljait és alapelveit a törvény 13 pontban foglalja össze, melyek közül a legfontosabbakat kívánjuk idézni:

- A tervezési régiók és tervezési zónák rendje illeszkedik az átfogó területi tervezés rendjébe, rendszerébe. Az átfogó területi tervezés ugyanakkor tekintettel van az egyes tervezési régiók és zónák adottságaira és igényeire. Az egymással szomszédos régiók és zónák tervezési rendszere illeszkedik egymáshoz. 
- A tartomány minden részén a lakosság igényeinek kielégítése érdekében törekedni kell az életfeltételek lehetőség szerinti azonos értékének megteremtésére és fenntartására, a gazdasági, a szociális, a közlekedési struktúrában lévő különbségek kiegyenlítése révén.

- A természeti életfeltételeket óvni és körültekintően kell igénybe venni, annak érdekében, hogy a jövö számára is megfelelö mennyiségben és minőségben elérhető legyen az. Különösen figyelemmel kell lenni a növények, az állatok, a föld védelmére, a levegő tisztaságára, a klíma védelmére, a kulturális javak, a táj-és helységkép megörzésére.

- További cél a helyes településstruktúra kialakítása, a lakosság alapszükségleteinek biztosítása, különös tekintettel a lakásról, lakhatásról, a közjavak, közszolgáltatások elérhetőségéröl való gondoskodásra, a kulturális, szociális, képzési, sport, információs, kommunikációs és közlekedési ellátottságra.

- A területi tervezés a gazdaság, az infrastruktúra, a lakásviszonyok, illetve a szükséges szerkezetátalakítás hosszú távú fejlesztésének alapjait biztosítja és javítja.

- A terulleti tervezés célja az életképes mező- és erdőgazdaság fenntartása, mely oly módon fejlesztendö, hogy biztosítható legyen a lakosság fenntartható ellátása élelmiszerrel és nyersanyagokkal, az agrárstruktúra javítása és az ökológiai állapot megőrzése mellett.

- További cél az üzemek és az ipar teljesítőképességének biztosítása és javítása, a helyi igényekre, az infrastruktúrára, különösen a környezet állapotára való tekintettel.

- A tervezés során meg kell akadályozni a víz és nyersanyag lelöhelyek olyan használatát, amely csökkenti, vagy gátolja azok kiaknázását. A vízierőmüvek használata szintén a tájkép védelme és az ökológiai egyensúly megőrzése mellett lehetséges.

- A köz- és magánszolgáltatások intézményrendszerét oly módon szükséges fejleszteni, hogy azok feladataik ellátása során lényegesen hozzájáruljanak a gazdaság növekedéséhez.

- Az idegenforgalmat az ökológiai terhelhetőségre tekintettel és a területek gazdasági erejéhez mérten, a természet- és tájvédelem követelményeire való tekintettel kell fejleszteni.

- A településszerkezetet úgy kell fejleszteni, hogy a népsürüség illeszkedjen a terület ökológiai és gazdasági teljesítőképességéhez, és a lehetö legjobb összhang alakuljon ki a lakóövezetek, a gazdasági vállalkozások, a közszolgáltatások, valamint a pihenőövezetek között.

A törvény saját maga számára is megfogalmaz bizonyos korlátokat, amikor megállapítja, hogy saját rendelkezései nem érinthetik a kormányzati kompetenciákat. Ezentúl a tervezés során figyelembe kell venni nem csupán a kormányzati, hanem a szomszédos tartományok intézkedéseit, szabályozását is. 


\section{A területrendezési terv}

A tervezésről szóló fejezeten belül a célok és alapelvek meghatározását követỏen a tartományi területrendezési terv elemeit határozza meg a burgenlandi jogalkotó. A terv a fentebb ismertetett célok és alapelvek figyelembevétele mellett alkotható meg. A terv jogforrását tekintve rendelet, melyet a tartományi kormány bocsát ki. A terv a rendelet szövegéböl és grafikai ábrából áll (pl. térképes ábrázolás). A dokumentum megalkotása során figyelemmel vannak a kormány, a szomszédos tartományok, az önkormányzatok és a tervezésben egyébként érdekeltek intézkedéseire. A terv kialakítása során meghallgatják az önkormányzatok, a Burgenlandi Mezőgazdasági Kamara, az Ipari Kamara, a Köz- és Magánalkalmazottak Kamarájának a véleményét. A tervezetet, véglegesítése előtt, a kormányzati hivatalban, valamint az önkormányzatoknál három hónapon keresztül közszemlére teszik, emellett a hivatalos közlönyben is megjelentetik. A tervezetre - a rendelkezésre álló idön belül minden választásra jogosult tartományi polgár megalapozott írásbeli észrevételt tehet. A véglegesítést megelőzỏen a tartományi kormány területi tervezési bizottsága a tervezetet megtárgyalja, melynek során a meghallgatási eljárás eredményeit és a megfelelő időben érkezett észrevételeket a tanácskozás során figyelembe veszik.

A törvény területi tervezésröl szóló fejezetében ezt követően egy kifejezetten rendezési jellegủ szabályozással találkozhatunk, amikor is az ún. fenntartott területekre vonatkozó rendelkezések felsorolására kerül sor. Ennek közvetlen oka az, hogy ezeket a területeket a területrendezési tervben is szerepeltetni szükséges. Ezt, a gyakorlatilag kisajátítást megelőző és a tulajdonosi jogokat alapvetően korlátozó jogot csak olyan igények kielégítésére lehet felhasználni, amelyek közösségi érdekeket szolgálnak. (5 éven belül e területek nem adhatók el, nem terhelhetők meg stb., viszont ezen idő lejáratát követően, - ha kisajátítási eljárás nem kezdődött -, ez az állapot automatikusan megszünik.)

A tartományi területrendezési terv csak akkor változtatható meg, ha azt a tervezési alapelvekhez kapcsolódó új okok indokolják, vagy a tervezési körülmény lényegesen megváltozik.

A terv minden önkormányzatra nézve kötelező érvényú.

\section{A terïleti kutatás}

A törvény önálló cím alatt rendelkezik egy igen fontos kérdésröl, a területi kutatás feladatáról. A jogszabály szerint a tartományi kormány a tervezés céljainak elérése érdekében, a területek eddigi állapota, valamint a természeti adottságok, gazdasági, kulturális, szociális feltetelek jövőbeni fejlesztése céljából kutatások megvalósítását biztosítja.

\section{Szervezetrendszer és eljárási rend}

A területi tervezés intézményrendszerében a tartományi kormány mellett a törvény további fontos szereplöt jelöl meg a területi tervezési tanács formájában. A 
tanács 13 tagból áll, elnöke a kormány azon tagja, aki a területi tervezési ügyek referense. Az alelnökök szintén a kormány tagjai közül kerülnek ki. Akadályoztatásuk esetén a kormányhivatal igazgatója vezeti az ülést szavazati joggal. A további tagokat a tartományi kormány nevezi ki: a Mezőgazdasági Kamara, az Ipari Kamara, a Köz- és Magánalkalmazottak Kamarája, az Osztrák Gyáriparosok Szövetsége burgenlandi egységének egy-egy képviselöjét, illetőleg az önkormányzatok és a tartományi ügyész két képviselöjét. A legnagyobb és a második legnagyobb önkormányzati érdekképviseletek biztosítják az önkormányzati oldal képviseletét. A tartományi parlamentben lévő pártok erőviszonyainak megfelelően négy személy kerül a tanácsba. A tanács megbízatása megegyezik a tartományi parlament mandátumával. Az új tanács az új választástól számított három hónapon belül alakul meg. A kormányhivatal igazgató tanácskozási joggal vesz részt az üléseken, melyekre további szakértőket is meghívhatnak.

A tanács ügyrendjéröl szólva a törvény megállapítja, hogy a tanácsot az elnök, akadályoztatása esetén a helyettese hívja össze, a napirend írásos kézbesítését követően, melynek legkésőbbi időpontja az ülést megelőző hetedik napon lehet. Ha a tartományi kormány, vagy legalább négy tag az ok megjelölésével írásban kéri, az elnök az ülést két héten belül köteles összehívni. A tanács határozatképes, ha tagjainak több mint fele jelen van, határozatait a jelenlévők egyszerü többségi döntése alapján hozza. Az ülésekről jegyzőkönyvet vezetnek, a jegyzőkönyvvezetöt a tartományi kormány hivatala biztosítja.

A tanács véleményt nyilvánít a fejlesztési programok és a területrendezési tervek tartalmáról és célkitűzéseiről, a kormányzat felhatalmazása alapján megállapítja a területhasznosítási tervek alkalmasságát, illetve eljár minden olyan tervezéssel kapcsolatos ügyben, amellyel a kormány megbízza.

\section{A fejlesztési program}

A törvény a területrendezési program mellett egy további programtípust is intézményesít, melyet fejlesztési program címmel illet. A fejlesztési program alaki jogforrása szintén rendelet formáját ölti. A fejlesztési program a tartomány, illetve egyes tartományrészek természeti, gazdasági, szociális, kulturális igényeinek megfelelỏ tervszerủ komplex kialakítása, a célok eléréséhez szükséges intézkedések megjelölése mellett. A jelzett elemeket a helyi területi tervnek is tartalmaznia kell, a fejlesztési program az önkormányzatok számára pedig éppúgy kötelező érvényü, mint a területrendezési program. A fejlesztési program kidolgozása természetesen a törvényben meghatározott alapelvek figyelembevétele mellett történhet mind tartományi, mind helyi szinten. A tartományi program kialakítása során ugyanúgy tekintettel kell lenni a kormányzati, ill. a szomszédos tartományok programjaira, mint a területrendezési program során azt bemutattuk. Az elökészítés során a véleményezésre felkért kamarák összetétele is ugyanaz, mint a területrendezési program esetén. 
Finta István : Az osztrák területi tervezés jogi szabályozásának vizsgálata.

Tér és Társadalom 18. évf. 2004/1. 107-126. p.

TÉT XVIII. évf. 2004

Kitekintö

113

Tájékoztatási kötelezettség

Külön érdemes kiemelni a tájékoztatási, adatközlési kötelezettség intézményét, amely jelen esetben nem a programalkotó kormányzatot terheli (a kormányzat ez irányú kötelezettsége a korábbiakban már ismertetésre került), hanem a terv alapján érintetteket, különös tekintettel az elektromos, közlekedési, szolgáltatási ágazatban müködö társaságokra. Az érintettek - az üzleti titkok sérelme nélkül - kötelesek felvilágosítást adni a tervezők számára a tervet érintő minden lényeges kérdésben.

\section{A helyi tervezés}

A törvény második - terjedelmileg legnagyobb fejezete - a helyi tervezéssel foglakozik. A helyi önkormányzatok ugyanis kötelesek saját hatáskörükben a területi terv keretén belül területhasznosítási tervet, valamint beépítési tervet készíteni, továbbá meghatározni az építési irányelveket. Érzékelhető, hogy a helyi területtervezési program elemeit alapvetően rendezési, technikai típusú normák alkotják, ezért ezek részletes bemutatását nem e tanulmány keretei között célszerủ elvégezni. Mindemellett indokolt legalább a fejezet címeinek felsorolása, amely kellóen alátámasztja a tartalom technikai jellegét. Az első cím az építési területek mobilizációjára vonatkozó rendelkezéseket tartalmazza, a továbbiakban pedig a következö területek részletes szabályozására kerül sor:

- területhasznosítási program meghatározása, tartalmi elemei, a módosítás szabályai, a program hatálya,

- építési terület, beépítési terv (részbeépítési terv), a terv tartalma és módosítási szabályai, a terv hatálya,

- építési irányelvek, határidős építési tilalmak,

- bevásárló centrumok,

- büntetö rendelkezések,

- közlekedési területek, zöldterületek, fenntartott területek,

- eljárási szabályok, a kártalanítás szabályai.

\section{A voralbergi területi tervezésról szóló törvény}

Az osztrák jogalkotási rendszerben - a burgenlandi mellett - a voralbergi tartományi törvény rendelkezik önállóan a területi tervezésröl. Mint ahogyan korábban jeleztilk, a törvények felépítése igen hasonló, azonban tartalmukban jelentős eltérések mutatkoznak. Ezért mindenképpen szükséges bemutatni az azonos címek alatti rendelkezéseket. 


\section{Alapelvek, célkitüzések}

A voralbergi területi tervezési törvény célkitüzései az alábbiakat foglalják magukban:

- az emberek részére történő területi egzisztenciális alapok fenntartása, különösen a lakás és a munkalehetőségek terén,

- a természet, a táj sokszínủségének fenntartása,

- a terület igényeinek lehető legjobb kielégítése és kiegyenlítése.

A tervezés során különösen az alábbi célokat szükséges szem elött tartani:

- a beépítés során takarékoskodni kell a rendelkezésre álló területekkel,

- a területhasználat különbözỏ alternatíváit lehetőség szerint hosszú távon változatlanul kell tartani,

- a természeti és a természetközeli tájegységek állapotát, valamint az ivóvízbázisok fenntartását biztosítani szükséges,

- a mező- és erdőgazdálkodásra különösen alkalmas területek más célú hasznosítása csak akkor tervezhető, ha azt nyomós közérdek támasztja alá,

- a lakás, a munka, a szabadidős, bevásárló és más egyéb rendeltetésủ területeket úgy kell egymáshoz illeszteni, hogy a (mindennemü) terhelés lehetőség szerint csökkenjék,

- azokat a területi struktúrákat, amelyek a szükségtelen individuális motorizált közlekedést idézik elö, meg kell szüntetni,

- a közösségi szükségleteknek megfelelő berendezkedést az adott hely igényeinek megfelelöen kell kialakítani.

A célok meghatározását követően a tervezés módjára vonatkozóan állapít meg a törvény - más jogszabályokban nem szereplö - rendelkezéseket. Ezek szerint - az érdekek kiegyensúlyozása céljából - az összes tervezés által érintett érdekeit úgy kell figyelembe venni, hogy az a lakosság, a közjó érdekeit a legjobban szolgálja. A tervet a magántulajdon lehetőség szerinti kímélete mellett kell megvalósítani.

\section{Intézményrendszer, eljárási szabályok}

A tervezés intézményrendszerével kapcsolatosan itt is megtalálható a tervezési tanács szervezete, amely a voralbergi kormányhivatal keretein belül müködik. A tanácsot elsősorban a tartományi területi tervek kibocsátása és módosítása, illetve a területhasználati tervek jóváhagyása elött hallgatják meg. Elnöke a tartományi kormány tagja, további tagjai a tartományi parlamentben szereplő pártok által delegáltak, valamint két tag a Mezőgazdasági Kamara képviseletében, egy-egy tag a Közés Magánalkalmazottak, ill. az Építész és Mérnöki Kamarából, négy tagot az önkormányzati szövetségek delegálnak, a Turisztikai, a Gyáriparosok és az Iparosok Szövetsége egy-egy taggal képviselteti magát. További négy személyt a tartományi kormány nevez ki azon szakemberek közül, akik a területi tervezés területén komoly jártassággal rendelkeznek, egy-egy képviselöt delegál a voralbergi „militärkommando", valamint a természet és tájvédelmi egyesület. 
A tanács müködésének szabályai lényegesen nem térnek el a burgenlandi törvényben már ismertetett részletektől (megbízatásuk ideje a tartományi kormány megbízatásának idejéhez igazodik, határozatait egyszerü többséggel hozza, Voralbergben évente kétszer, illetve szükség szerint ülésezik stb.). A tájékoztatási kötelezettség itt is megjelenik az előző törvényhez képest annyi eltéréssel, hogy az mindenkire vonatkozik, aki a tervezés szempontjából valamely lényeges információ birtokában van, illetöleg a törvény külön nevesíti az önkormányzatokat, melyek ezzel kapcsolatosan kötelesek az egyes elöterjesztések fontosabb indokait, alapjait ismertetni. Az Unió 96/82/EG irányelve alapján a törvény külön nevesíti az olyan vállalkozásokat, amelyek - súlyos balesetek okozására is képes - veszélyes anyagok feldolgozásával foglakoznak, valamint kötelezi öket kielégítö információ szolgáltatására abban az esetben is, ha tevékenységüket bővíteni, vagy fejleszteni kívánják.

A második fejezet határozza meg a tartományi területi tervek kibocsátásának szabályait, melyek alaki jogforrása Voralbergben is rendelet formáját ölti. A rendelet megalkotására abban az esetben kerül sor, ha a területi tervezés céljainak elérése ezt megköveteli. A terv alapvetően a tartomány egészére egységesen vonatkozik, azonban a törvény lehetöséget biztosít az igényeknek, illetve egyes ágazati érdekeknek megfelelö területrészek kijelölésére is.

A terv készítésének eljárási szabályozása nem tér el jelentősen a burgenlandi szabályozástól, tehát e tartományban is figyelembe kell venni az országos, a szomszédos tartományok és országok terveit, az önkormányzatok érdekeit. A tervezetet itt is mindenki számára hozzáférhetővé kell tenni, és meghatározott időtartamon belül biztosítani szükséges az észrevétel, javaslattétel lehetöségét minden állandó lakhellyel rendelkező voralbergi polgár számára. A részletszabályok teljes ismertetésétől eltekintve arra talán érdemes felhívni a figyelmet, hogy Voralbergben a jogalkotó a közszemlére tétel időtartamának csupán alsó határát vonta meg, mely legalább egy hónap. A közzétételi eszközök között a hagyományos információhordozók (tartományi, Mezőgazdasági Kamara közlönye, kifüggesztés) szerepelnek, az elektronikai eszközök igénybevételének lehetősége egyelöre nem jelenik meg a jogszabályban. A közzététel tartalmi elemeit vizsgálva a burgelandi szabályozáshoz képest új elem a terv grafikai, térképes megjelenítése, melyet egyedül a hivatalos közlönyben nem szükséges szerepeltetni.

A terv, illetőleg a rendelet hatálya tekintetében kimondja azt az általánosan ismert és alkalmazott elvet, hogy a terv nem lehet ellentétben más tartományi tervekkel, illetve jogszabályokkal. Új elem az a rendelkezés, amely szerint köztestületek, a magánjog keretein belül szabályozott alapítványok, alapok és szervezetek területi hatással rendelkező tevékenységének összhangban kell állnia a törvényben meghatározott célokkal, illetve csak a célokhoz igazodó tevékenységet folytathatnak.

A törvény bevezeti az ún. kivételi jogosultság intézményét, mely a tartományi kormányt illeti. E jogkör alapján „bizonyos elképzelések kivehetők a tervböl” (LGB1. 39/1996.), ha azok a terv céljait, illetve más területi tervezési célok elérését veszélyeztetik. Ezen felhatalmazás jogi természete szerint a hatósági mérlegelés 
(diszkrecionális jog) körébe tartozik, és megfelelő határidőkhöz, körülményekhez, feltételekhez igazodhat.

A terv módosítására akkor nyílik lehetöség, ha más jogszabályok változása ezt szưkségessé teszi, vagy a terv kialakítása során figyelembe vett tényezők jelentősen megváltoztak. A módosítás folyamata gyakorlatilag megegyezik a terv kialakítása során alkalmazott eljárás jogi szabályozásával.

A voralbergi jogszabály a területi tervezés fejezetén belül is szerepelteti az építési tilalom intézményét (Burgenlandban ez kizárólag a helyi önkormányzatok hatáskörébe tartozik), melyet a tartományi kormány rendelet formájában állapít meg. Ez a tilalom viszont legfeljebb csak két évig maradhat fenn, illetve egy ízben további egy évvel hosszabbítható meg. A határidők lejártát, illetve a tilalom okának megszúnését követően automatikusan megszủnik.

A második fejezet záró rendelkezései között szerepelnek az idegen telkek használatáról szóló szabályok, melyek alapvetően - a nálunk polgári törvénykönyvböl ismert - szolgalmi jog konkretizálását tartalmazzák.

\section{A helyi tervezés}

A törvény harmadik fejezetén belül a helyi önkormányzati tervezésre vonatkozó rendelkezések szerepelnek. Ezek részletes ismertetése - a burgenlandi elemzés során megfogalmazott indokokkal egybehangzóan - nem tủnik elengedhetetlennek. Általános tartalmáról kelló információt szolgáltatnak a fejezet föbb címei:

- fejlesztési koncepció (a területhasznosítás és beépítési terv alapelveinek meghatározására, a kívánatos gazdasági és település szerkezetre, a közlekedési hálózatra stb. vonatkozóan),

- területhasznosítási terv:

- építési területek, az építési területek megosztása,

- bevásárlóközpontokra vonatkozó rendelkezések,

- üdullőövezetek,

- szabadterületek, közlekedési területek,

- fenntartott területek,

- eljárási szabályok, a rendelet hatálya, kivételi jogosultság, módosítás, felülvizsgálat,

- építési tilalom, idegen telkek használata,

- döntés.

- beépítési terv:

- általános rendelkezések, eljárási szabályok, módosítás,

- az építés keretei (magasság meghatározás stb.), az építés típusa (nyitott, zárt beépítés stb.)

- lakóövezetre vonatkozó szabályok,

- telkek funkciói, területi jellegủ megosztása stb. 


\section{A tiroli területrendezési törvény}

Az osztrák területi tervezés jogszabályi vizsgálatát a tiroli területrendezési törvény ismertetésével zárjuk, mely egyben a legújabb (1997.) és legnagyobb terjedelmü jogszabály. Ez a jogszabály elnevezését tekintve ugyan nem a tervezéssel foglakozik, azonban tartalmát tekintve nem tapasztalható a tervezési tevékenység rendezésére utaló hiány a területi tervezés címet viselő jogszabályokhoz képest.

\section{Alapelvek, célok}

Az első fejezet (területi szintü területrendezés) általános rendelkezései a területrendezés céljait és feladatait határozzák meg. A törvény értelmében a tiroli területrendezés a tartomány rendezett és komplex fejlesztését szolgálja. A területrendezés célja különösen:

- a földek takarékos és célhoz kötött használata,

- a környezet ápolása és védelme, különös tekintettel a víz, a levegö, a föld tisztaságának megörzésére, illetve a tisztaság helyreállítására, valamint a zajterhelés csökkentésére,

- az érintetlen természet megőrzése, a biodiverzitás fenntarthatóságának biztosítása, a házi növény- és állatvilág természetes életterének biztosítása, a természeti és kultúrtajak sajátosságainak, szépségének és sokszínűségének ápolása és védelme,

- az élettér biztosítása, különös tekintettel a településeket és a fontos közlekedési utakat fenyegetỏ természeti veszélyek tekintetében,

- a lakott területek, az üdülöövezetek, a közlekedési útvonalak és az ökológiailag különösen értékes területek védelme a veszélyes anyagok használata során bekövetkező balesetek ellen, tekintettel a 96/82/EG irányelvre,

- a lakóterületeknek a lakosság lakásigényeit és megelégedését szolgáló fenntartása és továbbfejlesztése, az életfeltételeket hátrányosan befolyásoló környezeti ártalmak csökkentése mellett,

- a munkaerőpiac adottságainak, a lakosság, a gazdaság - környezetvédelmet szem elött tartó - igényeinek megfelelö, időszerủ és a teljesítóképességet szolgáló fenntartása és fejlesztése. Különös tekintettel a mezö- és erdőgazdálkodás számára szükséges területek biztosítása, az agrár-infrastruktúra javítása, az agrár üzemstruktúra fenntartása, az ipari területek biztosítása és a turizmus müködtetése érdekében.

- az üdülöterületek biztosítása, a közlekedési igények környezetvédelemnek megfelelő kielégítése, különös tekintettel a tömegközlekedés továbbfejlesztésére, a szükségtelen közlekedés csökkentésére,

- a forrás és talajvizek védelme, a környezeti ártalmakat csökkentő, megszüntető hulladékgazdálkodás, az energia takarékos és célszerü használatának biztosítása, különös tekintettel a házi és megújítható energiaforrások kihasználására, 
Finta István : Az osztrák területi tervezés jogi szabályozásának vizsgálata.

Tér és Társadalom 18. évf. 2004/1. 107-126. p.

- a képzési intézmények fenntartása és továbbfejlesztése, különös tekintettel az iskolai, a kulturális és sportlétesítményekre,

- a lakossági igények kiegyensúlyozott ellátása és fejlesztése a szociálisegészségügyi szolgáltatások területén,

- a lakosság és a gazdaság legszükségesebb igényeinek ellátása krízishelyzetekben,

- az önkormányzati közigazgatás fenntartása és fejlesztése, önkormányzatok együttmüködésének javítása.

\section{Tájékoztatási kötelezettség}

A célok meghatározását követően e törvény is rendezi az információszolgáltatási kötelezettség szabályait. E jogszabályban határozta meg legvilágosabban a jogalkotó azoknak a körét, akik e kötelezettség címzettje. Nem „,mindenki”, és nem csupán a köztestületek és magánjogi szervezetek lettek megjelölve, mint az elözőekben ismertetett két törvény során, hanem a tartomány, valamint az önkormányzatok minden szerve köteles a tervezést befolyásoló minden lényeges körülményröl a lehető legkorábban tájékoztatni a tartományi kormányt, illetve annak illetékes szervét. Ugyanakkor egy ellentétes irányú kötelezettség is megfogalmazódik a szabályozás során, ahol a kötelezetti oldalon a tartományi kormány áll minden olyan ügyben, amely lényegesen befolyásolhatja a helyi tervek elkészítését. A törvény meghatározza a lényeges ügyek körét, miszerint ide tartozik minden olyan tervezési tevékenység és intézkedés, amely nagyobb kiterjedésủ területek igénybevételére, a lehetséges területhasználat korlátozására, vagy megváltoztatására irányul, továbbá az olyan fejlesztés, amely befolyásolja a helyi területrendezési törek véseket.

\section{A kisrégiók}

A tiroli törvény a tartományi és a helyi szint között egy - eddigi jogszabályokból ismeretlen - területi szintet, a kisrégiók szintjét is intézményesíti. A kisrégiókat a tartományi kormány rendelet útján, területrendezési szempontból, a természeti, gazdasági, szociális és kulturális adottságok alapján határozta meg. A kisrégiók határai az önkormányzatok és járások határait nem vághatják át.

\section{Helyzetelemzés, elökészítés}

A területrendezési programra vonatkozó szabályozást megelözően a törvény két olyan tevékenységgel is foglalkozik, amelyek elösegítik a programalkotás eredményességét. Az első ilyen terület az állapotfelmérés, szakszerüen szólva helyzetelemzés. A tartományi kormány a helyzetelemzés során rögzíti a lényeges természeti, gazdasági, infrastrukturális, szociális és kulturális adottságokat és ezek elöre látható változásait. A második fontos tevékenység az elökészítés, melyet a tartományi kormány szervei, illetve a kormány által megbízott egyéb szervezetek végezhetnek el. Ezek a szervek készítik el a helyzetelemzést, illetve annak aktualizálását, valamint 
elökészítik a területrendezési terv alapjaira, alapelveire vonatkozó javaslatokat, közremüködnek egyéb technikai tevékenységek megvalósításában. A jelzett tevékenységeket úgy kell megvalósítani, hogy azok az érintett ingatlantulajdonosok érdekeit a legkevésbé sértsék. A szükséges tevékenységekröl a jogosult szervek írásban értesítik az érintetteket. A tulajdonosok, illetve a tulajdonosi jog gyakorlói türni kötelesek e tevékenységeket, illetőleg az azokhoz kapcsolódó telekhasználatot. Vita esetén e kérdésben a tulajdonos(ok) kérelmére a tartományi kormány jogosult dönteni. Sérelem esetén a tulajdonosok kártérítést igényelhetnek a tartománytól.

\section{Területrendezési program, terïletrendezési terv}

A területrendezési program Tirolban is rendelet formájában kerül kibocsátásra. A program megalkotása során figyelembe veszik azokat a helyzetelemzés során kialakított célokat, alapelveket, amelyek a törvényben meghatározott területrendezési célokkal, alapelvekkel összhangban állnak, és a tervezési területek szabályozott fejlődését eredményezik. A területrendezési program intézkedései között alapvetően ugyanazok a célok, intézkedések szerepelnek, amelyekkel az elöző két törvény bemutatása során már megismerkedhettünk (pl. ökológiailag értékes területek, nyersanyag, vízlelőhelyek, mezőgazdasági területek megőrzése, bizonyos területek biztosítása az ipari, az infrastrukturális, turisztikai beruházások számára stb.). Ugyanakkor szukségesnek tünik felhívni a figyelmet arra a rendelkezésre, mely szerint azoknak a tervezési területeknek a határai, amelyek csak a tartomány egy részére vonatkoznak, metszhetik a kisrégiók és az önkormányzatok határait, ha a program tartalma szerint ez indokolt.

A tiroli törvény kulön szabályozza a bevásárlóközpontok területrendezési programját, $s$ csak ezt követően tér rá az általános területrendezési program megalkotásának eljárási rendjére. Az eljárási szabályok nem sokban különböznek az elözỏ két törvény során már ismertetett szabályoktól, azonban a tiroli rendszerben külön nevesítik az önkormányzati szövetségeket és az innsbrucki városi önkormányzatot (az önkormányzatok és a különbözỏ kamarák mellett), mint azon címzetteket, akik számára a tervezetet elküldik állásfoglalás, javaslattétel érdekében. A nevezettek két hónapon belül tehetnek észrevételeket és módosító javaslatokat a tervezetre. Az önkormányzatok polgármesteri hivatalaiban négy héten át látható a tervezet, melynek véleményezésére az állandó lakhellyel rendelkezỏ személyek mellett a telephellyel, székhellyel rendelkező vállalkozások képviselöi is jogosultak.

A területrendezési program megváltoztatására - hasonlóképpen a már ismertetett törvényekhez - a program alapjául szolgáló tények megváltozása esetén van lehetőség, illetve új elemként jelenik meg a hazai alkotmányjogi, valamint a közösségi jog átvétele során fennálló kötelezettségek teljesítése érdekében szukséges változtatások lehetősége, továbbá a fontos közérdek alapján történö módosítás esélye.

A tiroli törvény is ismeri - hasonlóan a voralbergihez - a területrendezési programból történő kivétel, kivonás intézményét. A szabályozás ebben az esetben viszont konkrétabb, akkor nyílik rá mód, ha az adott önkormányzat írásbeli kérelmet 
terjeszt elő, melynek alapján a tartományi kormány felhatalmazhatja bizonyos területek meghatározott célú hasznosítására, illetve használatból történő kivonására. Mindennek feltétele az, hogy az önkormányzat az adott igényt a rendelkezésre álló területen nem, vagy nem racionálisan képes kielégíteni, illetve az igény kielégítéséhez közérdek füződik. A kérelemhez csatolni kell az érintett tulajdonosok nyilatkozatát. A döntést megelözően a tartományi kormány meghallgatja a területrendezési tanács érintett bizottságát. Pozitív döntés esetén is megszűnik az önkormányzat jogosultsága akkor, ha hat hónapon belül nem hasznosítja a kérelemnek megfelelöen az adott területet.

A jogalkotó e fejezeten belül olyan további speciális területek szabályozására vállalkozott, mint az üdülöterületek korlátozása, az üdülöépületek jegyzékének szabályozása, a meglévö üdülöövezetek bỏvítésének kérdése. Ezek után jutott el ismét néhány, olyan számunkra nem közömbös rendelkezéshez, mint például a területrendezési tervek területe, vagy a területrendezés szerveinek rendezése. A tiroli jogszabály különbséget tesz a területrendezési program és a területrendezési tervek között. Területrendezési tervek megalkotására abban az esetben van lehetőség, ha azok a tartomány egésze, vagy részei fejlődését segítik elő, és a területrendezési program nem érintette az adott terileteket, témaköröket. Ezek alapján a tervek lehetnek ágazatokon túlnyúló, integrált tervek, illetve ágazati, szektorális tervek. Kidolgozásukra a területrendezési programra vonatkozó szabályok az irányadóak, azzal az eltéréssel, hogy a javaslattételre rendelkezésre álló idő ebben az esetben egy hónap.

\section{Intézményrendszer, eljárási szabályok}

A területrendezés legfontosabb szerve - a tartományi kormányt követően - Tirolban is a területrendezési tanács. Elnöke - hasonlóan a két másik tartományhoz - a tartományi kormány tagja. A további öt tag öt kamara képviseletében látja el teendőit, egy-egy tagot pedig a Tiroli Önkormányzati Szövetség, az innsbrucki városi önkormányzat, az innsbrucki egyetem, az Osztrák Gyáriparosok Szövetsége, az Osztrák Iparegyesület területi szerve, a munkaügyi központ, a tartományi ügyész, valamint a kormányhivatal delegál (ez utóbbi a szakterület szerint illetékes ügyosztály vezetôjét delegálja).

A törvény - a korábban ismertetett jogszabályoktól eltérően - rendezi a kinevezés átfogó szabályait is. Ezek szerint a kinevezés az érintett szervezetek javaslata alapján történik. A javaslatokat a kormány megválasztásától számított egy hónapon belül kell megtenni. Ha ezen az időn belül nem érkezik javaslat, akkor a kormány annak hiányában is dönt a kinevezésrỏl. A tagsági viszony a tartományi parlamenti megbízatás időtartamához kötődik. A törvény felsorolja a tagsági viszony megszünésének eseteit, melyek között a visszahívás esete is megtalálható.

A jogszabály külön rendelkezik a területrendezési tanács bizottságairól, melyek meghatározott területekre, feladatok ellátására alakíthatók ki.

Más tartományokhoz képest teljesen új intézményeket honosít meg a tiroli törvény a járási bizottságok, valamint a regionális tanácsok formájában. 
A járási bizottságot e törvény hozza létre oly módon, hogy minden politikai járást (illetöleg testületét) felhatalmaz és egyben kötelez területrendezési ügyekben történö eljárásra. A bizottság elnöke a járási testület vezetője, további tagjai a regionális tanácsok elnökei, azok a polgármesterek, amelyek önkormányzata önmagában egy kisrégiót képez, a tartományi parlament járásban megválasztott tagja, az öt kamara illetékes képviselöi, a munkaügyi központ illetékes szervének vezetöje, négy további tag, akik kiemelkedő szakismerettel és tapasztalattal rendelkeznek a településfejlesztés és lakásügyek, az infrastruktúra-fejlesztés, a természet- és környezetvédelem, valamint a képzés és kultúra területén. Az innsbrucki járás bizottságának összetételére vonatkozóan különálló, az általánostól némiképp eltérő tagságot rendel a törvény.

A regionális tanácsokat a kisrégiókhoz illeszkedöen hozta létre e törvény. Minden egyes kisrégió - amely több önkormányzatot foglal magában - regionális tanácsot müködtet. A regionális tanács feladata a kisrégió területrendezéssel kapcsolatos ügyeinek szakmai előkészítése. A mindenkori regionális tanács tagjai a kisrégió minden önkormányzatának polgármestere, további négy olyan tag, akiknek az állandó lakhelye a kisrégió területén van, és kiemelkedő szaktudással és tapasztalattal rendelkeznek településfejlesztés és lakásügyek, az infrastruktúra-fejlesztés, a gazdaságfejlesztés, valamint a természet- és környezetvédelem területén. Legfeljebb négy olyan további tagja lehet a regionális tanácsnak, akik az imént jelzett területeken kívül a területrendezéshez kapcsolódó kiemelkedö tudással és tapasztalattal rendelkeznek. A tagokat - a polgármestereken kívül - a járási testület vezetőjének javaslatára a tartományi kormány nevezi ki. Az előterjesztést megelőzően a testület vezetöje meghallgatja a kisrégió önkormányzatainak javaslatát. A regionális tanács tagjainak megbízatása az önkormányzatok képviselö-testületeinek megbízatási idejéhez kötödik. Feladatukat mindaddig ellátják, amíg az új tagok kinevezése meg nem történik.

A törvény az összes területrendezési szerv ügyrendjét együtt szabályozza, ami gyakorlatilag megegyezik a korábbi két tartomány esetén már megismert jogi szabályozással (határozatképességhez legalább a tagok felének jelen kell lenni, határozataikat egyszerü többséggel hozzák stb.).

A jogszabály további részei a területrendezés helyi kérdéseivel foglakoznak, alapvetöen technikai, rendezési szempontok alapján. E szabályok ismertetése itt sem tünik alapvető fontosságú feladatnak.

\section{Következtetések}

$\mathrm{Az}$ ausztriai jogrendszer a területi tervezés jogi szabályozási feladatát az egyes tartományokra bízza. Ez elvileg megteremtheti a széttagoltság, az egymástól teljesen eltérö szabályozások kialakulásának lehetőségét, amely egy országon belül föként kis és nyitott nemzetgazdaságok esetén - egyáltalán nem kívánatos állapotot teremthet. Ausztriában az átfogó, országos szintủ tervezési jogszabály hiánya mellett - a jogi szabályozás területén - mégsem alakult ki ez a nemkívánatos helyzet, ehelyett a koherenciát is biztosító kilenc tartományi szintü területi tervezéssel foglalkozó jogszabály megalkotására került sor. A tartományi szintủ szabályozás poten- 
ciális veszélye előnyöket is hordoz magában azáltal, hogy biztosítja a területi adottságoknak, igényeknek, céloknak megfelelő területi jogszabály kialakításának lehetőségét. Ezt a lehetőséget - az elemzett jogszabályi rendelkezések tanúsága szerint - az egyes tartományi jogalkotók ki is használták, és például az alapelvek, vagy a területi szintek meghatározása során érvényesítették saját tartományuk igényeit, érdekeit.

A bevezetö általános megállapításokon túl szükségesnek tünik felhívni a figyelmet olyan, a tartalomhoz kötödö, illetőleg szabályozástechnikai sajátosságokra, amelyek esetleg tanulságosak lehetnek a magyar jogi szabályozás kialakítása során.

1) A jogszabály helye a jogrendszerben, illeszkedése más normákhoz

Az osztrák jogszabályok területi szintü törvény, illetve kormányrendelet (területi tervezésről, területrendezésről szóló program) formájában jelennek meg a jogrendszerben. Hazánk esetén ilyen megoldás nyilván nem képzelhető el, hiszen területi szinten nincs olyan jogalkotó szerv, amely mindenki számára kötelező erejü normát alkothatna. Ez viszont önmagában még nem zárja ki azt a lehetőséget, hogy valamely központi jogalkotó szerv (például az országgyülés, esetleg a kormány) a számára rendelkezésre álló valamely jogi norma segítségével kihirdesse a hét magyarországi régió saját maga által alkotott területfejlesztési, területrendezési programját. Az ilyen típusú megoldás egyúttal szolgálná a decentralizáció elvének (legalább részleges) érvényesülését és a területi sajátosságok figyelembevételét, valamint képes lenne biztosítani a program kötelező érvényét az adott jogszabály ereje által. Az alkotás (területi szintü) szabadsága és joga, valamint a jogszabályt kibocsátó központi szerv normaalkotáshoz füződő joga olyan konszenzusos helyzetet eredményezhetne, ahol együtt érvényesülhetnének a területi és az országos érdekek.

A más normákhoz történö illeszkedés kapcsán nem mellékes az, hogy minden törvény megköveteli a szomszédos tartományok, országok jogszabályainak, programjainak figyelembevételét. Külön érdemes felhívni a figyelmet arra, hogy a területi programok megalkotása során nem csupán a felsőbb szintü normákhoz kell alkalmazkodni, hanem figyelembe kell venni a helyi önkormányzatok érdekeit, tervezési tevékenységeit is. Ez utóbbi rendelkezéshez hasonló szabályozás mintha hiányozna a magyar jogalkotási gyakorlatból.

2) Alapelvek, célok

$\mathrm{Az}$ ismertetett jogszabályok viszonylag széleskörüen határozzák meg a területi tervezés alapelveit és céljait. Számos olyan elvvel vagy céllal találkozhatunk, amelyek hazánkban különbözö ágazati jogszabályokban szerepelnek. Mindemellett talán nem tünik haszontalannak ezen elvek, célok területi tervezést szabályozó normákban való elhelyezése, hiszen így alakítható ki egy olyan logikai lánc, amely akár az alkotmánytól kezdődően képes megjeleníteni, kibontani azokat az elveket, célokat, amelyek a (komplex) területi tervezés szempontjából fontosak. Ez különösen olyan esetekben lehet hasznos, amikor konkrét jogvita vagy jogértelmezés során elegendő a területre vonatkozó egységes jogi normára utalni, és nem szükséges más 
ágazati jogszabályokból - esetleg nehezebben azonosítható - jogokat, kötelezettségeket levezetni, illetőleg ezek hiányában az alkotmánybíróság határozatára várni.

Az osztrák jogszabályok alapelvei, céljai az alábbi főbb területek, tevékenységek szerint csoportosíthatók:

- az épített és természeti környezet védelme,

- a kiegyenlítés elvének érvényesítése,

- a helyes településstruktúra kialakítása,

- a megfelelö földhasználat biztosítása,

- az infrastruktúra fejlesztése (különös tekintettel a közlekedés, azon belül, a tömegközlekedés fejlesztésére),

- a közszolgáltatások biztosítása,

- a gazdaság fejlesztése (nevesítve az ipar, mezőgazdaság, idegenforgalom),

- közigazgatás fejlesztése.

Fontos hozzáfüzni, hogy az esetek többségében nem csupán a célokat jelöli meg a jogalkotó, hanem utal az eléréshez vezetỏ út során figyelembe veendő körülményekre is. Ezek a körülmények túlnyomóan a környezet védelméhez kapcsolódnak (pl. a vízierőmủvek használata szintén a tájkép védelme és az ökológiai egyensúly megőrzése mellett lehetséges), ritka esetben fordul elö a gazdaság, a társadalom fejlesztése során figyelembe vehető körülmény (pl. a munkaeröpiac igényeinek megfelelő fejlesztés).

Kifejezetten ugyan nem történik utalás a törvény legfontosabb céljának - területi tervezés - megvalósítási módjára, azonban az egyes rendelkezések alapján (pl. a program kialakításának, az elfogadott változat módosításának körülményei) egyértelmủen állítható, hogy a program hosszú távra készül, ami ezáltal biztosítja az érintettek számára a tervezhetöséget, a nemzetgazdaság számára pedig a kiszámítható, stabil müködés esélyét.

3) Eljárási szabályok

A területrendezési, területi tervezési programok megalkotásának egyes fázisaira vonatkozóan az osztrák jogszabályok viszonylag részletes útmutatást adnak. A tiroli törvény a helyzetelemzés és az elökészítés szakaszát is szabályozza, míg a vizsgált másik két jogszabály a tervezet nyilvánossá tételére, a társadalom, illetőleg az érintettek tervezési folyamatba történő bevonására, az érdekek, vélemények megjelenítésének módozataira helyezi a hangsúlyt (hivatalos közlöny, kifüggesztés, térképek, határidők, címzettek köre, írásos indokok stb.). A jogi szabályozás ezen formája példa értékủ lehet a magyar jogalkotó számára is.

A tájékoztatási kötelezettség különböző fejlettségi foka érzékelhető az egyes jogszabályok rendelkezései között. Alapesetben a köztestületek és magánjogi szervezetek kötelesek minden olyan információ közlésére, amelyek befolyásolhatják a területi tervek tartalmát. A következö lépcső az, amikor e kötelezetti körben fellelhető az összes önkormányzat, illetve állami intézmény. A legfejlettebb szabályozás során nem csupán az imént felsorolt címzettek állnak a kötelezetti oldalon, hanem 
maga a tartomány is, a helyi tervek vonatkozásában számára rendelkezésre álló érdemi információk tekintetében. A viszonosság ily módon történő megjelenítése, ismét mintaértékủ lehet a magyar szabályozás számára.

Talán az a kérdés sem mellékes, amely az elökészítésre, illetve a program kidolgozására vonatkozik a program elkészítésére való jogosultság, felhatalmazás szempontjából. Jelen pillanatban az készít hazánkban teruletfejlesztési programot, aki akar, illetve akit ezzel megbíznak. Ez némiképp jelzi a programoknak tulajdonított jelentőséget és rosszabb esetben a programok minőségét is. Ezzel szemben a rendezési-tervezési tevékenység elvégzésére nem mindenki jogosult, és - a fejlesztési tevékenységekkel kapcsolatosan - az is érzékelhetö, hogy például az uniós források, fejlesztések kezelésének feltétele egy akkreditációs folyamat. Talán nem lenne haszontalan a fejlesztési, rendezési tevékenységek alapjául szolgáló programok potenciális alkotóival szemben is egy követelményrendszert felállítani, amely esetleg hozzájárulhatna a minőségibb programalkotás kialakulásához.

\section{4) Intézményrendszer}

A területrendezés, területi tervezés intézményrendszere szerves része a jogalkotásnak, a jogalkotási folyamatnak, így maguk a szervezetek is a jogi normák kibocsátására jogosult szervek (tartományi parlament, illetve kormány) intézményrendszeréhez, olykor intézményrendszerébe illeszkednek. Ez a tény - a kormány után a legfontosabb intézmény - a területi tervezési, területrendezési tanács tagságán belül a vezető tisztségek kormánytagok által történő betöltése útján jut kifejezésre. Mindemellett az osztrák jogalkotó törekszik a társadalmi érdekek mind szélesebb körü megjelenítésének biztosítására, melyet a kamarák, a különböző érdekszövetségek és egyesületek, valamint a helyi önkormányzati társulások képviselete útján biztosít. Az egyes érdekek és szereplök közötti helyes képviseletei arány megválasztása nem könnyủ feladat, melynek eredménye a múködés, a müködőképesség vizsgálata során mérhető, a törvény szövegéböl legfeljebb csak sejthetö.

Az osztrák jogalkotó viszonylag részletesen rendelkezik a tagsági megbízatás elnyerésének módjairól, illetve a szervezetek ügyrendjéröl. A magyar jogalkotó például a társadalmi, szakmai szervezetek különböző döntésekbe, szervekbe történő bevonása során - sokkal elnagyoltabban foglakozik e kérdésekkel, bár fontosságuk egyáltalán nem tünik elhanyagolhatónak.

5) A jogszabály hatálya

A törvény, a rendelet érvényesülését biztositó rendelkezések szokásos körén túl a vizsgált jogszabályok tartalmaznak némi többletet. A jogszabály nem csupán kötelező a címzettekre nézve, de a rendelkezések azt is kimondják, hogy a területi folyamatokat befolyásoló tevékenység csak a törvény céljaira való tekintettel folytatható. Hazánkban ilyen típusú szabályozás föként az alacsonyabb szintú ágazati jogszabályok körében, ott is konkrét esetekre vonatkozóan jelenik meg (leírják egy konkrét tevékenység folytathatóságának feltételeit, módját stb.). Magasabb szintü jogszabályok valamely tevékenységtől való tartózkodást irányoznak elő (pl. Btk.), 
vagy éppen általánosabb és diszpozitív módon szabályozzák az egyes tevékenységek megvalósíthatósági módjait (pl. Ptk.). Talán megfontolásra érdemes - például a területfejlesztési törvényben - olyan rendelkezés beépítése, amely elöírja, hogy a területi folyamatokat érdemben befolyásoló fejlesztési tevékenység csak a törvényben meghatározott célok mentén folytatható. Ennek előnye lehet a fejlesztési tevékenységek mederbe terelése, összehangolása, hátránya viszont a bürokrácia reálfolyamatokba történő - sokszor negatív hatású - beavatkozási lehetóségének biztosítása.

A hatály kapcsán érdemes utalni a programból való kivétel lehetőségére, pontosabban annak feltételeiről szóló szabályozásra. Amennyiben hazánkban sor kerül hasonló jogintézmény bevezetésére, akkor - az osztrák rendelkezésekhez hasonlóan - minimálisan szükségesnek tủnik a közérdek és az igénykielégítés más módon nem teljesíthetőségének feltételkénti beépítése.

6) Speciális rendelkezések

A vizsgált jogszabályok területi tervezéssel foglalkozó részein belül találhatók bizonyos speciális rendelkezések, amelyek kifejezetten csak a tervezés egy részterületével foglalkoznak, vagy pedig - az általános jogszabályi felépítéstől eltérően - új intézményeket, tartalmi elemeket jelenítenek meg. A tervezés részterületeire vonatkozó rendelkezések alapvetỏen technikai, rendezési irányultságúak és az alábbiak szerint összegezhetök:

- bevásárlóközpontok szabályozása,

- fenntartott területek,

- építési tilalom szabályozása,

- üdülö övezetekre vonatkozó rendelkezések.

A területi tervezés általános tartalomtól eltérő - többnyire csak egy-egy jogszabályban megtalálható - elemei az alábbiak:

- területi kutatás szabályozása,

- fejlesztési program intézményesítése (a területrendezési programon túl),

- kisrégiók területi szintje,

- regionális tanácsok és járási bizottságok intézménye,

- területrendezési terv (a területrendezési program mellett).

Hazánk szempontjából talán tanulságos, hogy Ausztriában a területi kutatásoknak tulajdonítanak akkora jelentőséget és fontosságot, hogy azt egy tartományi törvény szintjén is szerepeltessék. A magyar közigazgatási, területfejlesztési reformmal kapcsolatosan érdekes lehet a kisrégiós területi szint és intézményrendszer, mely némiképp hasonlít a magyar kistérségek jelenlegi területi egységéhez, és bizonyos tekintetben példája lehet a kistérség jövöbeni intézményrendszerének. Külön érdemes felhívni a figyelmet az osztrák regionális tanács összetételére (polgármesterek, kamarák, társadalmi szervezetek, szakértők), mely széles társadalmi bázison nyugszik, míg a leendő magyar kistérségi tanács összetétele egyelöre bizonytalan, a jogszabálytervezetek alapján a társadalom részvételének ilyen szintủ biztosítása nem prognosztizálható. 
Finta István : Az osztrák területi tervezés jogi szabályozásának vizsgálata.

Tér és Társadalom 18. évf. 2004/1. 107-126. p.

A vizsgált jogszabályok bemutatásának lezárásával, illetöleg a fontosabb következtetések kifejtésének befejezése mellett megállapítható, hogy az egyes tartományi törvények területi tervezésre vonatkozó részei elősegíthetik mind a hazai értelemben vett területfejlesztés, mind pedig a területrendezés - különösen az alapelvek, célok meghatározására vonatkozó - jogszabályi rendezését. Az osztrák programozási gyakorlat leginkább a rendezési jellegü feladatok megvalósítása során támaszkodik az ismertetett törvényekre, tekintettel arra, hogy Ausztriában a területhasználat problémái sokkal jelentösebbek, mint a gazdaságfejlesztés gondjai. Ez természetesen nem jelenti azt, hogy a törvények alapelvei, céljai ne lennének alkalmasak akár a hazai - a területfejlesztési programozás gyakorlati tevékenységének megalapozására is. Az ismertetett rendelkezések jelentős része, valamint az osztrák jogalkotói szemlélet (pl. a társadalmi részvétel biztosítása tekintetében) mindenképpen figyelemre méltó lehet a magyar jogalkotó, a magyar jogalkotás számára.

\section{Irodalom}

Gesetz vom 20. März 1969 uber die Raumplanung im Burgenland. (1969)

Kundmachung der Landesregierung vom 23. Oktober 2001 über die Wiederverlautbarung des Tiroler Raumordnungsgesetzes 1997. (2001)

LGBI.Nr. 39/1996 Gesetz uber die Raumplanung in Voralberg (1996)

Schindegger, F. (1999) Raum, Planung, Politik. Böhlau, Wien, Köln, Weimar.

Zehetner, F. (2001) Republik Österreich. - Deutsch-Österreiches Handbuch der Planungsbegriffe. Verlag der ARL, Hannover. 99-189. o. 